\title{
PENGEMBANGAN KOMPETENSI GURU MELALUI PELATIHAN PTK DI SD NURUL HIKMAH SIDOARJO
}

\author{
M. Nur Rohim \\ mnurrohim.18015@mhs.unesa.ac.id \\ Program Studi Magister Manajemen Pendidikan Universitas Negeri Surabaya
}

\begin{abstract}
Improvement of the national education system is needed so that the quality of education increases one of the efforts to improve the quality of education is by increasing teacher professionalism. Increased professionalism of teachers is characterized by an increase in competencies that must be possessed by teachers, namely pedagogical competencies related to management of students, social competencies related to communication skills, personal competencies related to the ability of teachers to have wise personalities, and professional competencies related to ability teacher to master knowledge and improve the quality of learning. One way that can be taken in improving the quality of learning is to carry out classroom action research. Class action research is a research activity to solve learning problems. By conducting classroom action research, teachers are able to improve the learning process through a study of what is happening in their classrooms. The purpose of this training is to find out how far the teacher's knowledge and practices are about Classroom Action Research. The methods that will be used to provide this training include: lectures, questions and answers, discussions, assignments, individual guidance, and independent training in the form of projects. From the results of the overall evaluation of the implementation of the Classroom Action Research training at SD Nurul, Sidoarjo Wisdom was fairly successful, it was seen from the implementation indicators and the results obtained from this training with fairly good values.
\end{abstract}

Keywords: Training, Classroom Action Research.

\section{PENDAHULUAN}

Peningkatan mutu pendidikan dirasakan sebagai suatu kebutuhan bangsa yang ingin maju, dengan keyakinan bahwa pendidikan yang bermutu dapat menunjang mutu di segala bidang. Oleh karena itu, pendidikan perlu mendapat perhatian yang besar agar kita dapat mengejar ketinggalan dibidang ilmu pengetahuan dan teknologi yang mutlak kita perlukan untuk 
mempercepat pembangunan dewasa ini. Oleh karena itu pendidikan yang bermutu perlu mendapat perhatian yang serius dari pemerintah. Guru memegang peranan strategis terutama dalam upaya membentuk watak bangsa melalui pengembangan kepribadian dan nilai-nilai yang diinginkan. Dari dimensi tersebut, peran guru sulit digantikan oleh yang lain. ${ }^{1}$

Melalui pendidikan program mencerdaskan bangsa dapat ditingkatkan dan dikembangkan Sagala sejalan dengan itu maka perlu meningkatkan mutu pendidikan yang dilakukan dengan berbagai macam cara, salah satu cara adalah peningkatan kemampuan guru melibatkan murid dalam proses pembelajaran. Dalam proses pembelajaran sangat perlu adanya minat belajar, tanpa adanya minat yang baik tidak akan terlaksana proses pembelajaran yang benar. Minat belajat murid sangat penting dalam pencapaian keberhasilan pembelajaran, minat yang terbentuk sejak kecil sering terbawa seumur hidup. ${ }^{2}$

Semangat menerapkan pembelajaran yang ideal sesuai dengan kurikulum yang digunakan, sering terkendala oleh realita yang banyak dijumpai para guru ketika berada di dalam kelas. Pemasalahan yang ditemui sesungguhnya telah mengakar dari tahun ke tahun, yaitu suasana pembelajaran kurang kondusif, siswa kurang antusias, kurang memperhatikan pembelajaran, tidak terampil, aktifitas siswa untuk mengikuti pelajaran cukup rendah, yang aktif hanya dimonopoli oleh siswa tertentu saja, siswa ramai atau bermain sendiri, mengantuk, tidak semangat dan cenderung bersikap ke arah negatif, proses pembelajaran kurang interaktif, siswa kurang dapat memahami konsep dengan benar sehingga hasil belajar siswa kurang sesuai dengan apa yang diharapkan atau di bawah Kriteria Ketentuan Minimal (KKM). Belum lagi permasalahan yang muncul dari gurunya, yaitu kurangnya penguasaan guru di dalam kelas, rendahnya pemahaman dan bekal ilmu untuk memaparkan materi pelajaran, cara mengajar yang monoton, miskin ide dan kreatifitas dalam mengajar, dan jarang menggunakan media pembelajaran. $^{3}$

Berdasarkan Peraturan Pemerintah (PP) Nomor 18 Tahun 2007 tentang Guru, dinyatakan bahwa kompetensi yang harus dimiliki oleh Guru

\footnotetext{
${ }^{1}$ Zetty. (2017). Urgensi Penelitian Tindakan Kelas Bagi Peningkatan Profesionalitas Guru Antara Cita Dan Fakta. Jurnal Pendidikan Tindakan Kelas Volume 15, No. 2 Tahun 2017.

${ }^{2}$ Syaiful, Sagala. 2006. Konsep dan Makna Pembelajaran. Bandung: Alfabeta. 2006. 1

3 Asmani, Jamal Ma'mur. (2011). Tips Sukses PLPG (Pendidikan dan Pelatihan Profesi Guru). Yogyakarta : Diva Press.
} 
meliputi kompetensi pedagogik, kompetensi kepribadian, kompetensi sosial, dan kompetensi profesional yang diperoleh melalui pendidikan profesi. Kompetensi Guru tersebut bersifat menyeluruh dan merupakan satu kesatuan yang satu sama lain saling berhubungan dan saling mendukung. Kompetensi pedagogik guru merupakan kemampuan dalam pengelolaan pembelajaran siswa, meliputi pemahaman wawasan atau landasan kependidikan, pemahaman terhadap peserta didik, pengembangan kurikulum/silabus, perancangan pembelajaran, pelaksanaan pembelajaran yang mendidik dan dialogis, pemanfaatan teknologi pembelajaran, evaluasi hasil belajar, dan pengembangan peserta didik untuk mengaktualisasikan berbagai potensi yang dimilikinya. ${ }^{4}$

Keresahan yang dialami oleh para guru pada satu sisi mendorong upaya positif para guru untuk mau belajar dan meneliti secara wajar demi mendapatkan Kredit Poin untuk dapat naik pangkat ke jenjang lebih tinggi, namun ada sebagian guru yang memilih jalan pintas dengan memesan karya ilmiah pada pihak-pihak tertentu. Dampaknya, citra guru tercoreng dengan munculnya PAK (Penilaian Angka Kredit) palsu. Kejadian yang mencoreng citra sebagian guru tersebut sebenarnya tidak perlu terjadi jika para penentu kebijakan baik swasta maupun negeri mau dengan sungguhsungguh memperhatikan kebutuhan guru dalam mengembangkan kemampuan menulis karya ilmiah di antaranya Penelitian Tindakan Kelas. ${ }^{5}$

Berbekal pengalaman selama mengajar, semestinya guru harus senantiasa mencari solusi terhadap masalah yang ditemui di kelas, agar masalah di kelas segera teratasi, pembelajaran dapat berjalan lebih baik, proses belajar menjadi mudah dan menyenangkan, siswa lebih antusias dan mudah dalam memahami pelajaran. Semuanya itu berdampak pada keberhasilan proses dan hasil belajar siswa. Namun, fakta di lapangan ternyata tidak mudah. Hasil studi awal dengan mitra sekolah ditemukan bahwa guru-guru di SD Nurul Hikmah Sidoarjo menunjukkan rata-rata kompetensi yang baik, hal ini didapat dari kuisioner yang disebarkan disekolah guna mengetahui aspek kelemahan dari pihak sekolah. Peneliti disini menggunkan aspek kompetensi yang harus dimiliki guru sebagai tolak

\footnotetext{
4 Anonim. (2012). Kompetensi Pedagogik Guru. www.m-edukasi. web.id/2012/04/kompetensi-pedagogik-guru.html.

5 Depdiknas. (2005). "Penulisan Karya Ilmiah" dalam Materi Pelatihan Terintegrasi Jilid 3. Jakarta: Depdiknas Dirjen Pendidikan Dasar dan Mengengah Direktorat Pendidikan Lanjutan Pertama.
} 


\section{2 ][ Pengembangan Kompetensi Guru Melalui Pelatihan PTK}

ukur keberhasilan dan didapatkan hasil pada aspek profesionaisme guru secara umum masih tergolong baik namun berdasarkan wawancara dan pembagian instrument banyak guru yang mengisi skor cukup pada kolom instrumen tentang Penelitian Tindakan Kelas (PTK) sebesar 30\%. Itu artinya sekolah sejauh ini belum memberlakukan PTK sehingga guru disekolah ini belum memiliki pengetahuan yang luas terkait cara pembuatan PTK. Dan dari kepala sekolah sendiri masih akan memberlakukan kebijakan untuk membuat PTK untuk tahun ajaran 2019/2020. ${ }^{6}$

PTK terdiri dari penelitian, tindakan, dan kelas. Penelitian merupakan kegiatan mencermati suatu objek dengan menggunakan aturan metodologi tertentu untuk memperoleh data dan informasi yang bermanfaat dalam meningkatkan mutu suatu hal, serta menarik minat dan penting bagi peneliti. Tindakan adalah kegiatan yang sengaja dilakukan dengan tujuan tertentu, sedangkan kelas adalah sekelompok siswa yang dalam waktu yang sama menerima pelajaran yang sama dari seorang guru. ${ }^{7}$ Adapun menurut Kunandar, ${ }^{8}$ PTK merupakan penelitian tindakan yang dilakukan oleh guru sekaligus sebagai peneliti di kelasnya atau bersama-sama dengan orang lain (kolaborasi) dengan jalan merancang, melaksanakan, dan merefleksikan tindakan secara kolaboratif dan partisipatif yang bertujuan untuk memperbaiki atau meningkatkan kualitas proses pembelajaran di kelasnya melalui suatu tindakan tertentu dalam suatu siklus. ${ }^{9}$

Peningkatan kualitas pembelajaran yang dilakukan oleh guru dapat dilakukan melalui penelitian tindakan kelas. Dengan penelitian tindakan kelas, pembelajaran yang dihadirkan oleh guru akan menjadi lebih efektif. Penelitian tindakan kelas juga merupakan suatu kebutuhan guru untuk meningkatkan profesionalitasnya sebagai guru karena: 1) Penelitian tindakan kelas sangat kondusif untuk membuat guru menjadi peka ${ }^{10}$

\footnotetext{
${ }^{6}$ Kunandar. (2008). Langkah Mudah Penelitian Tindakan Kelas Sebagai Pengembangan Profesi Guru. Jakarta : Raja Grafindo Persada.

${ }^{7}$ Arikunto, Suharsimi. 2010. Prosedur Penelitian Suatu Pendekatan Praktik. Jakarta: Rineka Cipta.

${ }^{8}$ Kunandar. (2008). Langkah Mudah Penelitian Tindakan Kelas Sebagai Pengembangan Profesi Guru. Jakarta : Raja Grafindo Persada.

9 N.K. Setiawan. (2008). Kode Etik Penulisan dan Hakikat Pendekatan Ilmiah. Dalam Departemen Pendidikan Nasional. Materi Pelatihan Penulisan Artikel Ilmiah. Direktorat Penelitian dan Pengabdian Kepada Masyarakat. Direktorat Jenderal Pendidikan Tinggi. Departemen Pendidikan Nasional. Yogyakarta. 7-10 Agustus 2008.

10 Mulyasa. E. (2015). Penelitian Tindakan Sekolah Meningkatkan Produktivitas Sekolah. Bandung: Remaja Rosdakarya.
} 
dan tanggap terhadap dinamika pembelajaran di kelasnya. Guru menjadi reflektif dan kritis terhadap apa yang guru dan siswa lakukan; 2) Penelitian tindakan kelas meningkatkan kinerja guru sehingga menjadi profesional. Guru tidak lagi sebagai seorang praktisi yang sudah merasa puas terhadap apa yang dikerjakannya selama bertahun-tahun tanpa ada upaya perbaikan dan inovasi, namun dia bisa menempatkan dirinya sebagai peneliti di bidangnya; 3) Guru mampu memperbaiki proses pembelajaran melalui suatu pengkajian yang terdalam terhadap apa yang terjadi di kelasnya; 4) Penelitian tindakan kelas tidak mengganggu tugas pokok seorang guru karena dia tidak perlu meninggalkan kelasnya. Pemerintah untuk tahun 2007 telah memprogramkan peningkatan profesionalitas guru dengan menyediakan dana block grant yang salah. ${ }^{11}$

Guru memiliki kemampuan untuk membimbing anak, menciptakan wadah bagi anak untuk mengenali potensinya dan melatih untuk mengaktualisasikan potensi yang dimiliki. Salah satu upaya yang dapat dilakukan untuk mengembangkan kemampuan ini adalah dengan melaksanakan penelitian tindakan kelas. PTK dapat memberikan nilai tambah dan masukan dengan tujuan perbaikan mutu dan kualitas pendidikan di kelas/sekolah. Selain itu, PTK secara global dapat memberikan solusi terhadap permasalahan bangsa, terutama merosotnya mutu pendidikan nasional. ${ }^{12}$

Terkait dengan kebutuhan tersebut, tulisan ini akan membahas mengenai penelitian tindakan kelas (PTK) sebagai sumbangan gagasan alternatif yang dapat diterapkan oleh para guru dalam pengembangan profesinya. Tulisan ini secara ringkas akan membahas mengenai pelatihan PTK di SD Nurul Hikmah Sidoarjo.

\section{METODE}

Metode yang akan digunakan untuk memberikan pelatihan ini, meliputi: ceramah, tanya-jawab, diskusi, pemberian tugas, bimbingan perorangan, dan latihan mandiri dalam bentuk proyek. Metode ceramah,

${ }^{11}$ Ujeng, Dkk. ( 2017). Peningkatan Hasil Belajar Siswa Dengan Menggunakan Alat Peraga IPA Kelas IV SD Inpres 1 Siney. Jurnal Pendidikan Vol. 4 No. 6

${ }^{12}$ Mulia, Dkk. (2016). PTK (Penelitian Tindakan Kelas) Dengan Pembelajaran Berbasis Kearifan Lokal Dan Penulisan Artikel Ilmiah Di Sd Negeri Kalisube, Banyumas. Jurnal Penelitian Tindakan Kelas Vol. IX, No. 2 


\section{4 ][ Pengembangan Kompetensi Guru Melalui Pelatihan PTK}

tanya-jawab dan diskusi, digunakan pada saat pertemuan awal dan penyampaian materi pelatihan yang diberikan kepada peserta pelatihan.

Metode pemberian tugas dan bimbingan perorangan digunakan pada saat melatih peserta pelatihan membuat bagian-bagian dari komponen PTK secara parsial (bagian per bagian), sekaligus untuk mengukur sejauh mana kemampuan telah dimiliki peserta pada saat pelatihan, dalam hal ini tugas diberikan dalam bentuk yang sederhana. Setelah peserta pelatihan dirasa sudah memiliki kemampuan yang cukup, kemudian diberikan tugas mandiri sebagai proyek dalam kegiatan pelatihan ini, yaitu berupa TOR PTK.

Lokasi Penelitian Penelitian ini dilaksanakan di SD Nurul Hikmah Sidoarjo dengan obyek penelitian sebanyak 18 guru dari SD Nurul Hikmah Sidoarjo dengan waktu pelaksanaan pada tanggal 18 Mei 2019.

Jenis dan Sumber Data didapatkan dalam penelitian ini adalah data kualitatif dan data kuantitatif.

1. Data kualitatif yaitu data yang diperoleh dari aktivitas guru berupa data hasil observasi selama proses pelaksanaan

2. Data kuantitatif yaitu data yang diperoleh dari hasil tes yang diberikan kepada guru. ${ }^{13}$

Teknik Pengumpulan Data dilakukan melalui tiga cara, yaitu:

Tes, dilakukan untuk mengumpulkan informasi pemahaman guru tentang materi yang diajarkan kepada guru. Tes terdiri dari tes awal dan tes akhir. Observasi, dilakukan selama kegiatan pembelajaran berlangsung. Pelaksanaannya dilakukan dengan mengisi format yang telah disiapkan oleh peneliti dengan tujuan untuk mengetahui aktifitas dan perilaku subjek peneliti pada saat pembelajaran berlangsung. ${ }^{14}$

Analisa data dalam penelitian ini dilakukan setelah pengumpulan data. Adapun tahap-tahap kegiatan analisis data kualitatif adalah a) mereduksi data, b) menyajikan data, dan c) penarikan kesimpulan dan verifikasi.

1. Mereduksi Data

Mereduksi data adalah proses kegiatan menyeleksi, memfokuskan, dan menyederhanakan semua data yang telah diperoleh, mulai dari awal pengumpulan data sampai penyusunan laporan penelitian.

13 Sukanti. (2008). Meningkatkan Kompetensi Guru Melalui Pelaksanaan Penelitian Tindakan Kelas. Jurnal Pendidikan Akuntansi Indonesia. Vol. VI. No. 1. Tahun 2008.

${ }^{14}$ McNiff, Jean. (1992). Action Research: Principle and Practice. London: Routledge. 
2. Penyajian Data

Penyajian data dilakukan dalam rangka mengorganisasikan hasil reduksi dengan cara menyusun secara naratif sekumpulan informasi yang telah diperoleh dari hasil reduksi, sehingga dapat memberikan kemungkinan penarikan kesimpulan dan penarikan tindakan.

3. Penarikan Kesimpulan dan Verifikasi

Penarikan kesimpulan adalah proses penampilan intisari terhadap hasil penafsiran dan evaluasi. Kegiatan ini mencakup pencarian makna data serta memberi penjelasan. Selanjutnya dilakukan kegiatan verifikasi, yaitu menguji kebenaran, kekokohan, dan kecocokan makna-makna yang muncul dari data. Verifikasi data dimaksudkan untuk mengevaluasi segala informasi yang telah didapatkan suatu data yang diperoleh data dari informan, sehingga akan didapatkan suatu data yang validitas dan berkualitas serta hasil dari data tersebut dapat dipertanggung jawabkan kebenarannya. ${ }^{15}$

\section{HASIL DAN PEMBAHASAN}

Pelatihan Penelitian Tindakan Kelas bagi Guru untuk Meningkatkan Kualitas Pembelajaran di SD Nurul Hikmah Sidoarjo telah dilaksanakan dengan baik oleh tim. Namun demikian, tentunya ada beberapa hal yang perlu ditingkatkan, baik dalam hal kebaikan maupun kekurangannya, sebagai bahan pertimbangan pada kegiatan-kegiatan selanjutnya.

\section{Evaluasi Hasil Pelatihan PTK di SD Nurul Hikmah Sidoarjo}

Pada tahap kegiatan Training Need Analysis Assesment guruguru di SD Nurul Hikmah Sidoarjo, kelompok/peneliti berkoordinasi dengan Kepala Sekolah untuk menentukan pelatihan apa yang sekiranya sangat dibutuhkan oleh guru-guru disekolah. Setelah melakukan koordinasi dengan sekolah peneliti melakukan uji instrument melalui Google Form sebagai sarana awal penentuan kebutuhan guru. Setelah mendapatkan hasil yang ternyata guru-guru disekolah tersebut menempatkan skor cukup pada point PTK, karena pada point ini yang memilih terbilang cukup signifikan sebesar 30\% maka dengan keputusan peneliti diambillah pelatihan PTK di SD Nurul Hikmah Sidoarjo.

\footnotetext{
${ }^{15}$ Miles, Huberman \& Saldana. (1992). Qualitative Data Analysis: America: Arizona State University.
} 
296 ][ Pengembangan Kompetensi Guru Melalui Pelatihan PTK

Tebel 1. Rekap Hasil Pembagian Instrumen

\begin{tabular}{|c|c|c|c|c|c|c|c|c|c|c|c|}
\hline \multirow{2}{*}{ Nama Responded } & \multicolumn{11}{|c|}{ Nomor Instrumen } \\
\hline & 1 & 2 & 3 & 4 & 5 & 6 & 7 & 8 & 9 & 10 & 11 \\
\hline Amrilia novitasari & B & $\mathrm{B}$ & B & $\mathrm{B}$ & $\mathrm{B}$ & $\mathrm{B}$ & $\mathrm{B}$ & $\mathrm{B}$ & SB & SB & SB \\
\hline Nur Rahmawati & $\mathrm{B}$ & B & SB & SB & SB & $\mathrm{B}$ & $\mathrm{B}$ & $\mathrm{B}$ & SB & B & B \\
\hline Nur rohmawati & $\mathrm{B}$ & B & SB & $\mathrm{B}$ & $\mathrm{B}$ & $\mathrm{B}$ & B & $\mathrm{B}$ & B & B & $\mathrm{C}$ \\
\hline Ayu Fitria & $\mathrm{B}$ & B & B & $\mathrm{B}$ & $\mathrm{B}$ & $\mathrm{B}$ & $\mathrm{B}$ & $\mathrm{B}$ & B & SB & $\mathrm{B}$ \\
\hline Desy ardiana & $\mathrm{C}$ & B & $\mathrm{C}$ & $\mathrm{C}$ & $\mathrm{K}$ & B & B & $\mathrm{B}$ & SB & B & SB \\
\hline Azizah Indah Karsari & B & SB & $\mathrm{B}$ & $\mathrm{B}$ & $\mathrm{B}$ & $\mathrm{B}$ & B & B & B & B & $\mathrm{B}$ \\
\hline Muhammad Fajrul Falah & B & $\mathrm{B}$ & B & $\mathrm{B}$ & $\mathrm{C}$ & $\mathrm{C}$ & $\mathrm{B}$ & $\mathrm{C}$ & $\mathrm{C}$ & $\mathrm{B}$ & $\mathrm{B}$ \\
\hline Rindi Anifathur $R$ & B & $\mathrm{B}$ & $\mathrm{B}$ & $\mathrm{B}$ & $\mathrm{B}$ & $\mathrm{B}$ & $\mathrm{B}$ & $\mathrm{C}$ & $\mathrm{B}$ & B & $\mathrm{C}$ \\
\hline Dhewi Mufidah & B & $\mathrm{B}$ & $\mathrm{B}$ & $\mathrm{B}$ & B & $\mathrm{B}$ & $\mathrm{B}$ & $\mathrm{B}$ & $\mathrm{B}$ & SB & $\mathrm{B}$ \\
\hline Roy adi setiawan & $\mathrm{B}$ & B & B & SB & SB & $\mathrm{B}$ & $\mathrm{B}$ & $\mathrm{C}$ & SB & $\mathrm{B}$ & $\mathrm{B}$ \\
\hline Dian irmawati & $\mathrm{B}$ & $\mathrm{B}$ & SB & $\mathrm{B}$ & $\mathrm{B}$ & $\mathrm{B}$ & $\mathrm{B}$ & $\mathrm{B}$ & $\mathrm{B}$ & $\mathrm{B}$ & $\mathrm{B}$ \\
\hline Fitri Yulia Rachmawati & $\mathrm{B}$ & $\mathrm{B}$ & B & B & $\mathrm{B}$ & SB & SB & SB & SB & SB & SB \\
\hline Dian irmawati & $\mathrm{B}$ & $\mathrm{B}$ & SB & $\mathrm{B}$ & $\mathrm{B}$ & $\mathrm{B}$ & $\mathrm{B}$ & $\mathrm{B}$ & $\mathrm{B}$ & $\mathrm{B}$ & $\mathrm{B}$ \\
\hline Nur Ardi Pratama Putra & B & $\mathrm{B}$ & B & B & $\mathrm{B}$ & B & B & $\mathrm{B}$ & $\mathrm{B}$ & $\mathrm{B}$ & B \\
\hline Mufidah hanum & $\mathrm{B}$ & $\mathrm{B}$ & $\mathrm{B}$ & $\mathrm{B}$ & $\mathrm{B}$ & $\mathrm{B}$ & B & $\mathrm{B}$ & $\mathrm{B}$ & B & $\mathrm{B}$ \\
\hline Luciana Sovel & $\mathrm{B}$ & $\mathrm{B}$ & SB & SB & SB & B & SB & SB & SB & SB & $\mathrm{B}$ \\
\hline Sonia Noor Febrianty & $\mathrm{K}$ & $\mathrm{K}$ & $\mathrm{K}$ & $\mathrm{K}$ & $\mathrm{K}$ & $\mathrm{B}$ & $\mathrm{B}$ & $\mathrm{C}$ & $\mathrm{B}$ & $\mathrm{B}$ & $\mathrm{B}$ \\
\hline Emmy Juniarti & $\mathrm{B}$ & $\mathrm{B}$ & $\mathrm{B}$ & $\mathrm{B}$ & B & SB & SB & SB & SB & SB & SB \\
\hline Vivi Avia & $\mathrm{C}$ & $\mathrm{C}$ & $\mathrm{C}$ & $\mathrm{C}$ & $\mathrm{C}$ & B & B & $\mathrm{C}$ & B & $\mathrm{B}$ & $\mathrm{C}$ \\
\hline Nur Laili Alfiyana & $\mathrm{B}$ & B & B & $\mathrm{C}$ & B & B & B & $\mathrm{C}$ & B & C & C \\
\hline
\end{tabular}

Berdasarkan data penilaian guru menunjukkan menunjukkan bahwa kompetensi guru rata rata baik, namun pada kompetensi professional mendapatkan skor rata rata cukup. Setelah berdiskusi dengan kepala sekolah akhirnya diputusan untuk memfokuskan pelatihan pada aspek kompetensi professional guru, kemudian dibuatkanlah form dengan hasil dari 20 responden menunjukkan bahwa responden mengalami skor cukup yang terbilang cukup besar pada kompetensi untuk membuat penelitian tindakan kelas yaitu sebesar 30\% dan Pemanfaatan teknologi untuk pengembangan diri sebesar $20 \%$, selain kedua kompetensi tersebut skor menunjukkan rata rata baik. Dari analisis tersebut maka diadakanlah pelatihan tentang Penelitian Tindakan Kelas (PTK) berbasis IT dalam pengelolaannya.

Sekolah menyatakan sangat berkepentingan terkait kompetensi penyusunan Penelitian Tindakan Kelas. Melakukan PTK merupakan salah satu kompetensi yang harus dimiliki guru adalah kompetensi profesional, yang dalam praktiknya untuk guru golongan IV/a ke atas yang akan promosi kenaikan pangkat dan jabatan, harus memiliki nilai/kum yang berasal dari penelitian. Penelitian Tindakan Kelas (PTK) 
sebagai bagian dari penelitian tindakan (action research), yang bertujuan memperbaiki mutu praktik pembelajaran di kelas, makin banyak diminati. Tidak sedikit tenaga pendidik melakukan PTK dalam upaya mereka mengembangkan profesinya. Oleh karena itu, pengetahuan tentang PTK makin dibutuhkan.

Pada tahap sebelum melakukan pelatihan peneliti menyiapkan materi Presentasi meliputi teori-teori Penelitian Tindakan Kelas, tematema yang relevan untuk dipresentasikan ketika pelaksanaan pelatihan, dan teknis penyusunan TOR PTK. Materi-materi tersebut dipresentasikan oleh tim peneliti pada tanggal 18 Mei 2019 diikuti oleh 18 orang guru pengampu berbagai mata pelajaran, baik adaptif maupun produktif. Pada saat penyampaian materi PTK guru-guru sangat antusias dengan banyaknya pertanyaan yang disampaikan pada saat sesi tanya jawab terkait materi yang instruktur sampaikan. Tidak seorang guru pun yang meninggalkan acara pelatihan sampai semua acara selesai dilaksanakan. Hal ini diperkuat oleh adanya tabel penilaian evaluasi reaksi peserta pelatihan pada saat materi di sampaikan pada peserta.

Tabel 2. Evaluasi Reaction

\begin{tabular}{|c|c|c|c|c|c|}
\hline No Absen & $\begin{array}{c}\text { Memperhatikan } \\
\text { pemaparan }\end{array}$ & $\begin{array}{l}\text { Antusias } \\
\text { dengan } \\
\text { materi }\end{array}$ & $\begin{array}{c}\text { Melontarkan } \\
\text { pertanyaan }\end{array}$ & $\begin{array}{l}\text { Menanggapi } \\
\text { pemateri }\end{array}$ & $\begin{array}{c}\text { Penuh } \\
\text { semangat }\end{array}$ \\
\hline 1 & $\sqrt{ }$ & $\sqrt{ }$ & $\sqrt{ }$ & $\sqrt{ }$ & $\sqrt{ }$ \\
\hline 2 & $\sqrt{ }$ & $\sqrt{ }$ & & $\sqrt{ }$ & $\sqrt{ }$ \\
\hline 3 & $\sqrt{ }$ & $\sqrt{ }$ & $\sqrt{ }$ & $\sqrt{ }$ & $\sqrt{ }$ \\
\hline 4 & $\sqrt{ }$ & $\sqrt{ }$ & $\sqrt{ }$ & & $\sqrt{ }$ \\
\hline 5 & $\sqrt{ }$ & & & & $\sqrt{ }$ \\
\hline 6 & $\sqrt{ }$ & & & & $\sqrt{ }$ \\
\hline 7 & $\sqrt{ }$ & & & $\sqrt{ }$ & $\sqrt{ }$ \\
\hline 8 & $\sqrt{ }$ & $\sqrt{ }$ & & $\sqrt{ }$ & $\sqrt{ }$ \\
\hline 9 & $\sqrt{ }$ & & & & $\sqrt{ }$ \\
\hline 10 & $\sqrt{ }$ & $\sqrt{ }$ & $\sqrt{ }$ & & $\sqrt{ }$ \\
\hline 11 & $\sqrt{ }$ & $\sqrt{ }$ & & & $\sqrt{ }$ \\
\hline 12 & $\sqrt{ }$ & $\sqrt{ }$ & & $\sqrt{ }$ & $\sqrt{ }$ \\
\hline 13 & $\sqrt{ }$ & & & $\sqrt{ }$ & $\sqrt{ }$ \\
\hline 14 & $\sqrt{ }$ & & $\sqrt{ }$ & $\sqrt{ }$ & \\
\hline 15 & $\sqrt{ }$ & $\sqrt{ }$ & & & \\
\hline 16 & $\sqrt{ }$ & $\sqrt{ }$ & $\sqrt{ }$ & & $\sqrt{ }$ \\
\hline 17 & $\sqrt{ }$ & & & $\sqrt{ }$ & \\
\hline 18 & $\sqrt{ }$ & $\sqrt{ }$ & & & \\
\hline
\end{tabular}

Dari hasil pengamatan yang dilakukan oleh kelompok/tim peneliti memang rata-menunjukkan reaksi yang bagus, karena penyampaian materi yang tidak begitu cepat dan disisipi dengan contoh keseharian mengajar, sehingga terkesan seru dan mengasyikkan. Hasil dari tabel diatas memeng sesuai dengan fakta dilapangan bahwa guru-guru yang 


\section{8 ][ Pengembangan Kompetensi Guru Melalui Pelatihan PTK}

menjadi peserta pelatihan sangat antusias mendengarkan materi yang disampaikan, karena mereka sangat mengetahui pentingnya PTK untuk menjadikan mereka guru yang mampu membimbing peserta didik dengan memberikan pembelajaran ideal yang sesuai dengan kebutuhannya.

Untuk melihat hasil dari pelatihan ini sudah berdampak atau tidak pada peserta pelatihan tim peneliti memberikan pre test dan post test pada peserta. Dan mendapatkan hasil sebagai berikut.

Tebel 3. Hasil Pre Test dan Post Test

\begin{tabular}{|l|c|c|c|}
\hline \multicolumn{1}{|c|}{ Nama } & Pretest & Posttest & Peningkatan \\
\hline Elma Husniati, S.Pd & $\mathbf{6 0}$ & $\mathbf{7 5}$ & $\mathbf{1 5}$ \\
\hline Nur Rohmawati, SPd & $\mathbf{6 0}$ & $\mathbf{7 0}$ & $\mathbf{1 0}$ \\
\hline Azizah Indah K, S.Pd & $\mathbf{8 0}$ & $\mathbf{8 5}$ & $\mathbf{5}$ \\
\hline Mufidah Hanum, S.Pd & $\mathbf{6 5}$ & $\mathbf{8 5}$ & $\mathbf{2 0}$ \\
\hline Novi Aprilia, S.Pd & $\mathbf{7 0}$ & $\mathbf{8 0}$ & $\mathbf{1 0}$ \\
\hline Dian Irmawati, S.Pd & $\mathbf{6 5}$ & $\mathbf{7 5}$ & $\mathbf{1 0}$ \\
\hline Nur Rohmawati, S.Pd & $\mathbf{6 5}$ & $\mathbf{8 0}$ & $\mathbf{1 5}$ \\
\hline Rindi Arifathur, S.Pd & $\mathbf{7 0}$ & $\mathbf{8 5}$ & $\mathbf{1 5}$ \\
\hline Hasman Adiyanto, S.Pd & $\mathbf{7 5}$ & $\mathbf{8 5}$ & $\mathbf{1 0}$ \\
\hline Anis Dwi P, S.Pd & $\mathbf{7 0}$ & $\mathbf{8 0}$ & $\mathbf{1 0}$ \\
\hline Roy Adi Setiawan, S.Pd & $\mathbf{4 5}$ & $\mathbf{7 0}$ & $\mathbf{2 5}$ \\
\hline Rofi', S.Pd & 50 & $\mathbf{7 5}$ & $\mathbf{2 5}$ \\
\hline Etty Rochmawati, S.Pd & $\mathbf{6 5}$ & $\mathbf{8 0}$ & $\mathbf{1 5}$ \\
\hline Noor Hikmah, S.Pd & $\mathbf{4 0}$ & $\mathbf{7 5}$ & $\mathbf{3 5}$ \\
\hline Nur Ardi P, S.Pd & $\mathbf{7 0}$ & $\mathbf{8 5}$ & $\mathbf{1 5}$ \\
\hline Etty Rochmawati, S.Pd & $\mathbf{6 5}$ & $\mathbf{7 0}$ & $\mathbf{5 0}$ \\
\hline Ananda Kurniasari, S.Pd & $\mathbf{6 5}$ & $\mathbf{7 5}$ & $\mathbf{1 0}$ \\
\hline Presentase Peningkatan & & & $\mathbf{1 4 , 7}$ \\
\hline
\end{tabular}

Dari hasil uji pre test dan post test diperoleh hasil bahwa ada peningkatan pada tiap guru atau peserta pelatihan dan rata-rata kemampuan peningkatannya sebesar $14,7 \%$ sebelum dan sesudah mengikuti pelatihan. Dengan adanya hasil pre test dan post test ini pelaksanaan pelatihan ptk di sd nurul hikmah sidoarjo bisa dikatakan mampunyai dampak bagi peserta pelatihan jika dilihat dari aspek pengetahuan tentang manfaat, dan pentingnya ptk bagi peningkatan mutu pembalajaran. Oleh karena itu karena guru atau peserta pelatihan sudah mendapat bekal yang cukup tentang ptk maka diharapkan guru dan pihak sekolah mampu mengimplementasikan pelatihan yang didapat dengan membuat PTK dengan memanfaatkan IT yang ada disekolah.

Setelah mendapatkan materi tentang ptk peserta pelatihan akan mendapatkan arahan untuk membuat ptk di sekolah, tetapi karena berhubung pada saat pelatihan berlangsung terkendala masalah waktu pelaksanaan akhirnya tim peneliti menagmbil jalan tengah dengan peserta 
pelatihan dibagi menjadi beberapa kelompok dengan instruksi membuat term of reference (tor) ptk. Tor ini adalah kerangka yang akan menjadi acuan dari ptk yang akan dikerjakan oleh masing-masing peserta pelatihan. Dengan adanya tor ini diharapkan akan mempermuda guru ketika akan membuat ptk nya sendiri untuk peningkatan mutu pembelajarannya. Kelompok tersebut bisa dilihat pada tabel dibawah ini.

Tabel 3. Pembuatan TOR PTK

\begin{tabular}{|l|c|c|c|c|}
\hline \multicolumn{1}{|c|}{ Komponen TOR } & Kelompok 1 & Kelompok 2 & Kelompok 3 & Kelompok 4 \\
\hline Latar Belakang & 90 & 85 & 70 & 70 \\
\hline Rumusan Masalah & 85 & 85 & 90 & 80 \\
\hline Tujuan Penelitian & 80 & 80 & 80 & 80 \\
\hline Hipotesis Tindakan & 90 & 60 & 80 & 85 \\
\hline Indikator Keberhasilan & 90 & 90 & 90 & 90 \\
\hline Manfaat Penelitian & 85 & 85 & 70 & 80 \\
\hline Landasan Teori & 80 & 70 & 80 & 90 \\
\hline Metode Penelitian & 80 & 70 & 70 & 70 \\
\hline $\begin{array}{l}\text { Kerangka Hasil Penelitian dan } \\
\text { kerangka Analisa Penelitian }\end{array}$ & 90 & 80 & 80 & 80 \\
\hline Daftar Pustaka & 90 & 80 & 80 & 90 \\
\hline TOTAL NILAl & 86 & 78,5 & 79 & 81,5 \\
\hline
\end{tabular}

Berdasarkan tebal diatas bisa dikatakan setiap kelompok mempunyai skor yang cukup baik jika dilihat dari total nilai setiap kelompok karena tidak ada kelompok yang nilainya dibawah KKM yang telah ditetapkan yakni sebesar 75. Dari tiap-tiap komponen yang dimiliki semua kelompok rata-rata nilai 80 yang terbilang baik. Dari beberapa hasil uji kinerja tersebut bisa dikatakan para peserta sudah bisa memahami konsep dan mampu mengaplikasikan dengan membuat TOR PTK.

Dari pengalaman melakukan penelitian, guru menyadari kekurangannya dan berusaha melakukan perbaikan dan perubahan serta meningkatkan kemampuannya. Guru sadar akan perlunya upaya-upaya pembaruan, inovasiinovasi dalam pembelajaran untuk mendukung perbaikan. Melalui pengalaman melakukan penelitian, guru memahami hubungan antara gagasan atau teori dengan praktik mengajar guru dan belajar siswa dalam kesehariannya, dan kesadaran ini akan menumbuhkan rasa percaya diri pada guru, kemudian meningkat menjadi rasa harga diri dan kualitas keprofesionalan guru.

Ideanya PTK sebagai media untuk meningkatkan profesionalitas guru dalam realitanya tidak sesuai harapan, karena masih banyak ditemukan kendalakendala dalam pelaksanaan PTK bagi guru. Kendala 
ini bisa berupa ketidak pahaman guru tentang cara pelaksanaan dan penulisan PTK, jadwal guru yang padat sehingga tidak sempat melakukan penelitian, pola pikir guru bahwa PTK itu sulit dan guru yang tidak memahami tentang manfaat pelaksanaan PTK bagi guru, peserta didik ataupun lembaga sekolah.

\section{KESIMPULAN}

Penelitian Tindakan Kelas merupakan salah satu jenis kegiatan pengembangan profesi guru. Jenis penelitian ini pada dasarnya merupakan kegiatan penelitian yang dilaksanakan guru dalam kelasnya dan hasilnya dapat digunakan untuk memperbaiki mutu praktik pembelajarannya. PTK betujuan untuk meningkatkan mutu proses dan hasil pembelajaran siswa di kelas maupun sekolahnya. PTK berfokus pada kelas atau proses pembelajaran yang terjadi di kelas, bukan pada input kelas sehingga PTK harus bertujuan atau mengenai hal-hal yang terjadi di kelas.

PTK merupakan bagian penting dari upaya pengembangan profesi guru karena dengan PTK mampu membelajarkan guru untuk berfikir kritis dan sistematis, sert membelajarkan guru untuk menulis. Untuk itu perlu kiranya guru secara terus menerus mengupayakan diri melakukan penelitian tindakan kelas demi peningkatan/perbaikan pembelajarannya di kelas dan pengembangan diri sebagai guru profesional.

Dari hasil pelaksanaan secara keseluruhan pelaksanaan pelatihan Penelitian Tindakan Kelas di SD Nurul Hikmah Sidoarjo terbilang cukup sukses dilakukan, hal itu jika dilihat dari indikator-indikator pelaksaan dan hasil yang didapatkan dari pelatihan ini dengan nilai-nilai yang cukup bagus, secara keseluruhan pelaksaannya sangat baik disamping para pelaksana pelatihan memberikan kemampuan terbaiknya ketikan pelatihan dimulai dan para guru yang menjadi peserta pelatihan sangat antusias sekali dari awal sampai akhir mendengarkan materi dan arahan dari pelaksana pelatihan. Oleh karena itu tim peneliti pelaksana pelatihan ini mengharapkan guru-guru di SD Nurul Hikmah Sidoarjo bisa membuat PTK tiap tahunnya untuk pengembangan diri dn perbaikan proses pembelajaran di dalam kelas untuk menciptakan mutu yang berkualitas dan menjadi contoh bagi sekolah lain dalam hal pembuatan PTK sekolah. 


\section{DAFTAR PUSTAKA}

Anonim. (2012). Kompetensi Pedagogik Guru. www.m-edukasi. web.id/2012/04/kompetensi-pedagogik-guru.html.

Arikunto, Suharsimi. 2010. Prosedur Penelitian Suatu Pendekatan Praktik. Jakarta: Rineka Cipta.

Asmani, Jamal Ma'mur. (2011). Tips Sukses PLPG (Pendidikan dan Pelatihan Profesi Guru). Yogyakarta : Diva Press.

Depdiknas. (2005). "Penulisan Karya Ilmiah" dalam Materi Pelatihan Terintegrasi Jilid 3. Jakarta: Depdiknas Dirjen Pendidikan Dasar dan Mengengah Direktorat Pendidikan Lanjutan Pertama.

Kunandar. (2008). Langkah Mudah Penelitian Tindakan Kelas Sebagai Pengembangan Profesi Guru. Jakarta : Raja Grafindo Persada. . (2007). Guru Profesional, Implementasi KTSP dan Sukses dalam

Sertifikasi Guru. Jakarta : PT RajaGrafindo Persada.

N.K. Setiawan. (2008). Kode Etik Penulisan dan Hakikat Pendekatan Ilmiah. Dalam Departemen Pendidikan Nasional. Materi Pelatihan Penulisan Artikel Ilmiah. Direktorat Penelitian dan Pengabdian Kepada Masyarakat. Direktorat Jenderal Pendidikan Tinggi. Departemen Pendidikan Nasional. Yogyakarta. 7-10 Agustus 2008.

McNiff, Jean. (1992). Action Research: Principle and Practice. London: Routledge.

Miles, Huberman \& Saldana. (1992). Qualitative Data Analysis: America: Arizona State University.

Mulia, Dkk. (2016). PTK (Penelitian Tindakan Kelas) Dengan Pembelajaran Berbasis Kearifan Lokal Dan Penulisan Artikel Ilmiah Di Sd Negeri Kalisube, Banyumas. Jurnal Penelitian Tindakan Kelas Vol. IX, No. 2

Mulyasa. E. (2015). Penelitian Tindakan Sekolah Meningkatkan Produktivitas Sekolah. Bandung: Remaja Rosdakarya.

Moloeng, Lexy J. (2011) .Metodologi Penelitian Kualitatif. Bandung: Remaja Rosdakarya.

Peraturan Pemerintah (PP) Nomor 18 Tahun 2007

Syaiful, Sagala. (2006). Konsep dan Makna Pembelajaran. Bandung: Alfabeta

Sugiyono. (2007). Metode Penelitian Pendididikan Pendekatan Kuantitatif Kualitatif. Bandung: Alfa Beta 
302 ][ Pengembangan Kompetensi Guru Melalui Pelatihan PTK

Sukanti. (2008). Meningkatkan Kompetensi Guru Melalui Pelaksanaan Penelitian Tindakan Kelas. Jurnal Pendidikan Akuntansi Indonesia. Vol. VI. No. 1. Tahun 2008.

Suyanto. (1997). Pedoman Pelaksanaan Penelitian Tindakan Kelas (PTK)., Bagian satu. Jakarta: Dirjen Dikti Depdikbud Proyek Pendidikan Tenaga

Ujeng, Dkk. ( 2017). Peningkatan Hasil Belajar Siswa Dengan Menggunakan Alat Peraga IPA Kelas IV SD Inpres 1 Siney. Jurnal Pendidikan Vol. 4 No. 6

Widayati, Ani (2008). Penelitian Tindakan Kelas. Jurnal Pendidikan Akuntansi Indonesia. Vol. VI No. 1

Zetty. (2017). Urgensi Penelitian Tindakan Kelas Bagi Peningkatan Profesionalitas Guru Antara Cita Dan Fakta. Jurnal Pendidikan Tindakan Kelas Volume 15, No. 2 Tahun 2017. 